\title{
Analysis of paralytic shellfish poisoning toxin congeners by a sodium channel receptor binding assay
}

\author{
Gires Usup*, Chui-Pin Leaw, Mei-Yee Cheah, Asmat Ahmad, Boon-Koon Ng \\ Marine Science Programme, Fakulti Sains dan Teknologi, Universiti Kebangsaan Malaysia, 43600 Bangi, Selangor, Malaysia
}

Received 5 January 2004; accepted 25 March 2004

Available online 12 May 2004

\begin{abstract}
This study was carried out to characterize the detection and quantitation of several paralytic shellfish poisoning (PSP) toxin congeners using a receptor binding assay (RBA). This involved competitive binding of the toxin congeners against tritiumlabeled STX for receptor sites on rat brain sodium channels. Competitive binding curves were described by a four-parameter logistic equation. Half-saturation values $\left(\mathrm{EC}_{50}\right)$ ranged from $4.38 \mathrm{nM}$ for STX to $142 \mathrm{nM}$ for GTX5. Receptor binding affinity was in the order STX $>$ GTX1/4 $>$ neoSTX $>$ GTX2/3 $>$ dcSTX $>$ GTX5, and this was similar to the order of mouse toxicity of these congeners. Predicted toxin concentrations from observed STXeq values and $\mathrm{EC}_{50}$ ratios relative to STX were within $20 \%$ or better of the actual concentrations used in the assay. In contrast predicted toxin concentrations using mouse toxicity ratios relative to STX did not provide a good match to actual concentrations, except for GTX1/4. This study has shown that the rat brain sodium channel RBA will provide a reliable integration of total toxicity of various PSP toxin congeners present in a sample.

(C) 2004 Elsevier Ltd. All rights reserved.
\end{abstract}

Keywords: Paralytic shellfish poisoning; Paralytic shellfish poisoning toxin detection; Receptor binding assay; Sodium channel

\section{Introduction}

Many countries face seafood toxicity problems related to harmful algal blooms (HABs). One of the most serious and widely distributed is paralytic shellfish poisoning (PSP). Most countries that have a history of PSP occurrence have a monitoring program in place to safeguard public health and meet seafood trade requirements. Currently many countries use the live mouse bioassay for this purpose, a method officially recognized by the AOAC (1997). The mouse bioassay does not require sophisticated instrumentation, is relatively simple to perform and it integrates total toxicity of a sample, which is an advantage for regulatory purposes. However, while the mouse bioassay has served its purpose relatively well for almost 50 years, recently there have been serious efforts to develop a replacement, particularly for

\footnotetext{
* Corresponding author. Tel.: +60-3-8921-3207; fax: +60-3 8925-3357.

E-mail address: gires@ukm.my (G. Usup).
}

monitoring purposes. The often cited weaknesses of the mouse bioassay are poor sensitivity and use of large numbers of live animals for testing.

Several alternative methods are available for the detection of PSP toxins, some more developed and/or quantitative than others. Of the analytical methods, HPLC has been the most well-developed (Sullivan et al., 1985; Oshima, 1995), while LC/MS methods are also getting more established (Quilliam et al., 2001). At present these analytical methods are considered more suited for research rather than monitoring purposes. Available assay methods are of three types, based on antibodies against the PSP toxins (Carlson et al., 1984; Usleber et al., 1997; Laycock et al., 2000), based on cell viability (Jellett et al., 1992; Van Egmond et al., 1993; Manger et al., 1997), and based on binding of PSP toxins to specific receptors (Doucette et al., 1997; Negri and Llewellyn, 1998). Of these methods, the competitive receptor binding assay (RBA) is considered as a very promising alternative to the mouse bioassay. Comparative studies, albeit still limited, have shown good 